\title{
Comparing the effects of resource enrichment and grazing on a bacterioplankton community of a meso-eutrophic reservoir
}

\author{
Karel Šimek ${ }^{1,2, *}$, Karel Horňák ${ }^{2}$, Michal Mašín ${ }^{2}$, Urania Christaki $^{3}{ }^{3}$ Jiří Nedoma $^{1}$, \\ Markus G. Weinbauer ${ }^{4,5}$, John R. Dolan ${ }^{5}$
}

${ }^{1}$ Hydrobiological Institute of the Academy of Sciences of the Czech Republic, and ${ }^{2}$ University of South Bohemia, Faculty of Biological Sciences, Na sádkách 7, 37005 České Budějovice, Czech Republic

${ }^{3}$ Institute of Oceanography, National Centre for Marine Research, PO Box 712, Anavìssos 19013, Attiki, Greece

${ }^{4}$ Netherlands Institute for Sea Research (NIOZ), Department of Biological Oceanography, POB 59, 1790 AB Den Burg, Texel, The Netherlands

${ }^{5}$ Marine Microbial Ecology Group, Laboratoire d'Océanographie de Villefranche (LOV), UMR 7093 CNRS-UPMC, BP 28 , 06234 Villefranche-sur-Mer, France

\begin{abstract}
We examined changes in a microbial community in reaction to shifts in predation pressure and resources in a meso-eutrophic reservoir. Manipulations consisted of size fractionation and either in situ incubation or transplantation from the dam area to the river area, which differed in P-availability. Three treatments, in which samples were incubated for $96 \mathrm{~h}$ in dialysis bags, were used: a bacterivore-free $(<0.8 \mu \mathrm{m})$ treatment, an enhanced flagellate grazing $(<5 \mu \mathrm{m})$ treatment and a control treatment (all bacterivores present). We monitored bacterial abundance, mean cell volume (MCV), bacterial production, protistan grazing, as well as bacterial community composition (BCC) using fluorescence in situ hybridisation (FISH) with oligonucleotide probes with different levels of specificity. Populations transplanted to the relatively P-rich river area showed a 3- to 6-fold increases in bacterial and heterotrophic nanoflagellates (HNF) abundance and bacterivory compared to the corresponding treatments incubated at the dam area. In the transplanted community, nearly all phylogenetic groups of bacteria distinguished showed increased growth rates, even in the top-down manipulation treatments of increased bacterivory. In contrast, at the more resource-limited dam, the top-down manipulations induced significant changes in bacterial community composition. Thus, we found that BCC changes with predation in resource-limited bacteria but that predation plays a minor role when resource limitation is relaxed.
\end{abstract}

KEY WORDS: Reservoir - Top-down and bottom-up control · Dialysis bags $\cdot$ Microbial food webs · Bacterivory $\cdot$ Bacterial community composition $\cdot$ RNA-targeted oligonucleotide probes

Resale or republication not permitted without written consent of the publisher

\section{INTRODUCTION}

A topic of hot debate in aquatic ecology today is the relative importance of different mechanisms in controlling bacterioplankton stocks and community structure. Recent studies have suggested that bacterioplankton can be regulated by temperature, resources (bottom-up control), grazing (top-down control) or viral lysis (e.g. Wright 1988, Sanders et al. 1992, Fuhrman 1999). Top-down control has received perhaps the most attention. Heterotrophic nanoflagellates (HNF) and ciliates are often considered the major predators of bacteria (e.g. Sanders et al. 1989, Šimek et al. 1990, Berninger et al. 1991). Moreover, many experimental studies have shown that protistan predation and zooplankton grazing yield changes in the freshwater bacterioplankton community in terms of size structure and also community composition (e.g. Chrzanowski \& Šimek 1990, Jürgens 1994, Hahn at al. 1999, Šimek et al. 1999). 
Selective protistan bacterivory has been suggested as one of the key factors regulating bacterial community composition (BCC) of natural freshwater assemblages (e.g. Jürgens et al. 1999, Šimek et al. 1999, 2001b, Langenheder \& Jürgens 2001). However, the interplay of selective and unselective predation is probably quite complex and changes in the grazer community may have varying effects on BCC. Pernthaler et al. (2001b), for example, reported that different species of protistan bacterivores could either suppress or support the growth of particular microbial populations. Additionally, the metazooplankton community can alter the size structure and community composition of the protistan grazers (e.g. Pace et al. 1990, Jürgens 1994), which suggests that the entire framework of the top-down forces directly or indirectly shaping BCC may be quite complex.

Overall, a variety of predation-related impacts on BCC have been documented in a variety of laboratory and in situ studies in freshwaters (e.g. Šimek et al. 1997, 1999, Hahn et al. 1999, Jürgens et al. 1999, Hahn \& Höfle 2001). In contrast, experiments in freshwaters reporting bottom-up control of BCC in situ are limited to circumstantial observations (e.g. after an algal bloom; Van Hannen et al. 1999), and much less is known about whether and how the top-down effects on BCC depend on nutrient supply rates.

Considering bottom-up factors, changes in apparently limiting nutrients are known to yield shifts in bulk properties of bacterioplankton communities, such as abundance, production and biomass (e.g. Chrzanowski et al. 1995, Schweitzer \& Simon 1995). However, details of such changes, i.e. which individual bacterial groups shift in relative proportions or absolute abundance in the community as a response to sudden changes in the availability of different nutrients, have rarely been studied under in situ conditions (e.g. Riemann et al. 2000, Schäfer et al. 2001).

To describe community level, bulk property, and responses of bacteria to change in bottom-up supply rates, a broad variety of experimental approaches and designs have been used from whole system manipulations (Pace \& Cole 1996) through to large enclosure experiments (e.g. Riemann \& Søndergaard 1986a) and small volume mesocosm or bottle experiments (e.g. Toolan et al. 1990, Chrzanowski et al. 1995, Schweitzer \& Simon 1995). These studies generally examined the effects of large shifts in resources, but even small modifications in the nature of a substrate and its availability can induce distinct changes in bacterial communities, yielding 'enrichment-specific' changes in BCC (e.g. Eilers et al. 2000, Pernthaler et al. 2001a). Thus, results of such experiments may not necessarily yield conclusions applicable to in situ conditions (see e.g. Gasol \& Duarte 2000).
The approach employed here was the exploitation of the natural heterogeneity existing in canyon-shaped reservoirs that show a strong longitudinal gradient of major chemical and biological parameters (Comerma et al. 2001, Šimek et al. 2001a, Gasol et al. 2002). Bottom-up differences encountered along such gradients might be responsible for the observed differences in $\mathrm{BCC}$, as differences in BCC have sometimes been found to be related to varying bottom-up supply rates (e.g. Riemann et al. 2000, Šimek et al. 2001a, Gasol et al. 2002).

The canyon-shaped Ř́mov reservoir has a strong downstream longitudinal gradient in trophic status (from eutrophy to mesotrophy), microbial and chemical parameters (Mašín et al. unpubl., Hejzlar et al. unpubl.), with the most pronounced differences between the river inflow and the reservoir dam. In this study, we employed an approach allowing the simultaneous assessment of the influences of bottom-up and top-down factors. Samples taken from the P-limited dam area were size-fractionated to produce different levels of protistan bacterivory and then incubated in situ in the sampling area, as well as in the relatively Penriched river area. The samples were incubated in dialysis bags which allowed for a relatively free exchange of inorganic and organic solutes. Thus, bacterioplankton grew at ambient temperature and nutrient concentrations, but were subjected to different levels of bacterivory (cf. Šimek et al. 2001b). The same bacterial community was exposed to markedly different bottom-up conditions (dam vs river site), but the same top-down manipulations.

\section{MATERIALS AND METHODS}

Study site and experimental design. The experiment was run in the canyon-shaped Rímov reservoir (South Bohemia, $470 \mathrm{~m}$ a.s.l.; area, $2.06 \mathrm{~km}^{2}$; volume, $34.5 \times$ $10^{6} \mathrm{~m}^{3}$; length, $13.5 \mathrm{~km}$; maximum depth, $43 \mathrm{~m}$; mean depth, $16.5 \mathrm{~m}$; mean retention time, $100 \mathrm{~d}$; dimictic, meso-eutrophic). In the experiment, we exploited a strong longitudinal downstream gradient in nutrients and dissolved (DOC) and particulate organic carbon between the river inflow and the dam area of the reservoir (Table 1) which likely yields differences in the resource control of microbial communities. Water was collected from the dam area of the reservoir at a sampling site located above the former river valley about $250 \mathrm{~m}$ from the reservoir dam. On 12 June 2000, water samples from the dam area were collected with a 21 Friedinger sampler from a depth of $0.5 \mathrm{~m}$ (20 samples) and mixed in a 501 plastic container. From a final volume of 40 l, $10 \mathrm{l}$ of the mixed sample were used for further micro- and zooplankton analyses. The experiment 
was conducted during the late clear water phase (12 to 16 June 2000, at water temperatures of 23 to 24 and $\sim 18^{\circ} \mathrm{C}$ at the dam area and the river inflow, respectively).

We used a size-fractionation approach to alter levels of bacterivory in natural populations (previously used in Šimek et al. 1999, 2001b) and monitored changes in bacterioplankton subjected to either negligible, or to high levels of protistan or zooplankton bacterivory. To compare bottom-up factors, aliquots of the same size-fractionated plankton samples (see below) collected at the dam area were incubated at the dam site and the river inflow of the reservoir, which has higher concentrations of phosphorus (Table 1), a transplant treatment similar to that employed by Gasol et al. (2002).

The size fractions represented: (1) 'bacterivore-free' treatment, via filtration through $0.8 \mu \mathrm{m}$ pore-size filters, which were assumed to remove all bacterivorous protists; (2) 'increased bacterivory' treatment via filtration through $5.0 \mu \mathrm{m}$ pore-size filters, which removed the predators of HNF, and thus allowed their rapid growth; and (3) control, untreated sample. To size-fractionate, water samples collected at the dam area were sequentially filtered through 5 and $0.8 \mu \mathrm{m}$ pore-size Poretics filters (47 mm diameter, OSMONIC) into the following fractions: $<5 \mu \mathrm{m}$ (bacteria and HNF only), $<0.8 \mu \mathrm{m}$ (bacteria only) or unfiltered (all bacterivores and HNF predators present). These fractions incubated in dialysis bags are designated throughout the text as $<5 \mu \mathrm{m}$, $<0.8 \mu \mathrm{m}$ and 'unfiltered' (Unf) treatments, respectively. The duplicate water fractions were placed in $\sim 2.51$ pre-treated (deionized water rinsed and boiled) dialysis tubes (diameter $75 \mathrm{~mm}$, molecular weight cut-off [MWC] 12000 to 16000 Da, Poly Labo). (For more details concerning filtration procedures see Šimek et al. 1999, 2001b). The dialysis bags were deployed in duplicates of the same size fractions at the dam area of the reservoir and transplanted into the river inflow area. All treatments in both study sites were incubated at a depth of $0.5 \mathrm{~m}$, and oriented horizontally in open Plexiglas holders. Samples ( 300 to $450 \mathrm{ml}$ ) were taken from each dialysis bag at times 0, 48, 72 and $96 \mathrm{~h}$.

Bacterial abundance and biomass. Subsamples were fixed with formaldehyde (final concentration, $2 \% \mathrm{wt} / \mathrm{vol}$ ), stained with DAPI (final concentration, $0.2 \% \mathrm{wt} / \mathrm{vol}$ ), and enumerated by epifluorescence microscopy (Olympus BX-60). Between 450 and 700 DAPI-stained bacterial cells were recorded at a magnification of $1000 \times$ with an analogue monochrome CCD camera (Cohu) mounted on the microscope and processed with the semiautomatic image analysis systems LUCIA D (Lucia 3.52, resolution $750 \times 520$ pixels, 256 grey levels, Laboratory Imaging). (Details of the image processing are given by Posch et al. [1997]). Bacterial biomass was calculated according to the allometric relationship between cell volume and carbon content described in Simon \& Azam (1989) and modified by Norland (1993). As cell width showed very little variability, cell length was the most important factor determining cell volume and the availability of bacterial prey to protists. Cells longer than $4 \mu \mathrm{m}$ and the flocs $>4 \mu \mathrm{m}$ (sized across) were assumed to be protected against grazing by most bacterivorous protists (Šimek et al. 1999, Hahn \& Höfle 2001) and thus, were labelled 'inedible' bacterial biomass.

Bacterial production. Bacterial production was measured with the thymidine incorporation method, basically following the procedure described by Riemann \& Søndergaard (1986b). Duplicate $5 \mathrm{ml}$ subsamples were incubated for $30 \mathrm{~min}$ at in situ temperature with $10 \mathrm{nmol}$ $\mathrm{l}^{-1}$ [methyl- $\left.{ }^{3} \mathrm{H}\right]$ thymidine (Amersham), then preserved with neutral buffered formaldehyde (final concentration, $2 \% \mathrm{wt} / \mathrm{vol})$, filtered through $0.2 \mu \mathrm{m}$ membrane Poretics filters (25 mm diameter, OSMONIC) and extracted 10 times by $1 \mathrm{ml}$ of ice-cold 5\% TCA (Šimek et al. 1999). Replicate blanks prefixed with $2 \%$ formaldehyde were processed in parallel. To determine an empirical conversion factor (ECF) between the thymidine incorporation rate and bacterial cell production rate, we used the data from the replicated $<0.8 \mu \mathrm{m}$ treatments incubated in situ at the dam area and the river inflow. The cell production rate was calculated from the slope of the in- 
crease of ln bacterial abundance over time $(0,48 \mathrm{~h})$. Our determined ECFs $\left(1.44 \times 10^{18}\right.$ and $1.98 \times 10^{18} \mathrm{cells} \mathrm{mol}^{-1}$ thymidine for the dam site and river inflow, respectively) were used for calculations.

Fluorescence in situ hybridisation (FISH) with oligonucleotide rRNA targeted probes. Analysis of BCC relied on in situ hybridisation with fluorescence oligonucleotide probes on membrane filters (Alfreider et al. 1996). For details of the hybridisation procedure and error estimates see Pernthaler et al. (1998). Briefly, bacterial cells from 10 to $20 \mathrm{ml}$ subsamples were filtered onto white $0.2 \mu \mathrm{m}$ pore-size Poretics filters (47 mm diameter, OSMONIC), then fixed on membrane filters by overlaying the filters with $4 \%$ paraformaldehyde in phosphate-buffered saline (PBS; $\mathrm{pH}$ 7.2) and stored at $-20^{\circ} \mathrm{C}$ (Alfreider et al. 1996). Seven different group-specific oligonucleotide probes (Interactiva) were targeted to the domain Bacteria (EUB338), the $\alpha-, \beta$ - and $\gamma$-subclasses of the class Proteobacteria (ALF968, BET42a and GAM42a), to the Cytophaga-Flavobacterium (CF319a) phylum (Amman et al. 1995) and to 2 phylogenetically narrower clusters of the $\beta$-proteobacteria and the Cytophaga-Flavobacterium phylum (probes R-BT065 and R-FL615, respectively). Throughout the text, the probe groups are simply designated as EUB, ALF, BET, GAM, CF, R-BT and R-FL. For the specific targets of the sequences and the nucleotide sequence accession numbers see Šimek et al. (2001b). The probes were fluorescently labelled with the indocarbocyanine dye Cy3 (Interactiva). After hybridisation, the filter sections were stained with DAPI and the percentage of hybridised bacterial cells enumerated by epifluorescence microscopy (Olympus, AX70 PROVIS). At least 500 DAPI-stained cells per sample were inspected. The mounting medium Citifluor (Citifluor) was amended with ca. $20 \%$ (vol/vol) of VectaShield (Vector Laboratories). This modification resulted in significantly reduced fading of the probe signal (J. Pernthaler pers. comm.).

Protozoan abundance and grazing impact. To measure protozoan grazing on bacterioplankton, we used fluorescently labelled bacterioplankton (FLB, Sherr \& Sherr 1993) concentrated from the reservoir water. (The experimental protocol is detailed and discussed in Šimek et al. [1999, 2001b].) Briefly, FLB uptake experiments were run in each of the bags containing protists at each time point. Flagellate and ciliate uptake rates were determined in the same treatment where FLB added constituted 5 to $15 \%$ of bacterial natural abundances. We determined ciliate grazing rates in time series from 5 to 15 min subsamples (only unfiltered treatments) and flagellate grazing rates in subsamples from 10 to $30 \mathrm{~min}$, respectively. Samples from $t_{0}$ were also inspected to avoid potential biases of our data due to attachment of non-ingested tracers on protozoan sur- faces. Usually $5 \mathrm{ml}$ (flagellates) or $20 \mathrm{ml}$ (ciliates) subsamples were stained with DAPI, filtered through $1 \mu \mathrm{m}$ black Poretics filters and inspected via epifluorescence microscopy (Olympus, AX70 PROVIS) to count protists and to analyse uptake rates. Non-pigmented, HNF and plastidic flagellates were differentiated. At least 50 ciliates and 100 flagellates were inspected for FLB ingestion in each sample. To estimate total protozoan grazing, we multiplied average uptake rates of ciliates and flagellates by their in situ abundances.

Zooplankton. At the beginning of the experiments, zooplankton $>40 \mu \mathrm{m}$ were concentrated from $10 \mathrm{l}$ (see above), preserved in $4 \%$ formaldehyde (final concentration) and quantified by direct counts of several subsamples (McCauley 1984). At the end of the experiments, the whole volume of water remaining in the dialysis bags containing unfiltered samples at the dam area and river inflow $(\sim 1000 \mathrm{ml})$ was concentrated and zooplankton composition was analysed.

Chlorophyll a (chl a) concentration. Chl a concentration was determined after filtration through Whatman GF/C filters. Filters with retained seston were ground, extracted in $90 \%$ acetone and measured spectrophotometrically after Lorenzen (1967).

Chemical parameters. DOC was analysed by means of a Shimadzu TOC-5000A analyser, and total and dissolved reactive phosphorus were determined by a spectrophotometric method described in Kopáček \& Hejzlar (1993).

Statistical analysis. For tests of differences in the proportions of the respective genotypic groups of bacteria, data were first normalised by arc-sine transformation. A 2-way analysis of variance (ANOVA) was used to compare changes in the proportions of the respective genotypic groups of bacteria among filtration treatments $(<0.8 \mu \mathrm{m},<5 \mu \mathrm{m}$ and Unf), and incubation site, i.e. dam versus river at times 48,72 and $96 \mathrm{~h}$. One-way ANOVAs were applied to test for treatmentspecific responses in the proportions of the cells detected with each rRNA-targeted probe separately at dam and river sites at times 48,72 and $96 \mathrm{~h}$. When these ANOVAs were significant, pair-wise comparisons between individual treatments were made by means of Tukey's HSD test (Stell \& Torrie 1980).

\section{RESULTS}

\section{Major characteristics of the dam area and the river inflow}

Table 1 shows the chemical parameters and chl a concentration from the dam area on Day 1 of the experiment compared to the average value of daily samples from the river inflow over the $4 \mathrm{~d}$ study period. 
The data illustrate the difference between the 2 sites with total phosphorus (TP) and dissolved reactive phosphorus (DRP) lower by a factor of 18 and 48, respectively in the dam waters compared to the river site. The amount of DOC was only slightly larger in the river inflow. Samples taken directly from the dialysis bags at the end of incubations showed markedly higher concentrations of TP and DRP in the samples transplanted to the river compared to those incubated at the sampling site, while the bulk of DOC showed no clear trend at both sites (Table 1).

\section{Bacterial and protozoan dynamics in different treatments}

Dam water communities, transplanted upstream to the river inflow area, showed markedly different temporal trends compared to microbial communities incubated at the sampling site. For example, in the bacterivore-free, $<0.8 \mu \mathrm{m}$ dam treatment, bacterial populations increased only by a factor of 1.5, while the same bacterial assemblage transplanted to the river water (Table 1) grew by a factor of $\sim 6$ and reached $21 \times 10^{6}$ cells $\mathrm{ml}^{-1}$ at $t_{72}$. Correspondingly, bacterial production and biomass (data not shown) of the transplanted populations were on average about 5 times higher and the overall bacterioplankton doubling time was shorter, decreasing from 78.3 to only $22.8 \mathrm{~h}$ (Table 2 ). The transplanted bacterial populations also showed a greater increase in mean cell volume (MCV, from 0.08 to $0.25 \mu^{3}$ ) between $t_{0}$ and $t_{48}$, followed by a moderate decrease (Fig. 1).

In contrast to the bacterivore-free treatments, the grazing-enhanced populations $(<5 \mu \mathrm{m})$ and untreated sam-

Table 2. Net doubling times of ungrazed microorganisms in the predator-free treatment ${ }^{\mathrm{a}}(<0.8 \mu \mathrm{m}$, bacterioplankton and different bacterial groups), in the $<5 \mu^{\mathrm{b}}$ (heterotrophic nanoflagellates, HNF) and of grazed HNF in the unfiltered treatment ${ }^{\mathrm{C}}$ exposed at the dam area compared to those transplanted to the river inflow. The values are mean \pm range of 2 duplicate treatments. Rates were calculated for intervals with exponential growth. See Fig. 4 for details

\begin{tabular}{|lccr|}
\hline Organisms & $\begin{array}{c}\text { Exposed at } \\
\text { the dam site } \\
\text { Doubling time }(\mathrm{h})\end{array}$ & $\begin{array}{c}\text { Transplanted to } \\
\text { the river site }\end{array}$ & $\begin{array}{c}\text { Interval } \\
(\mathrm{h})\end{array}$ \\
\hline Bacterioplankton & $78 \pm 10$ & $23 \pm 2$ & $0-48^{\mathrm{a}}$ \\
CF & $220 \pm 30$ & $620 \pm 60$ & $0-48^{\mathrm{a}}$ \\
BET & $43 \pm 2$ & $13 \pm 0.2$ & $0-48^{\mathrm{a}}$ \\
R-BT & $24 \pm 1$ & $14 \pm 0.2$ & $0-48^{\mathrm{a}}$ \\
GAM & $25 \pm 0.1$ & $12 \pm 0.2$ & $0-48^{\mathrm{a}}$ \\
HNF & $16 \pm 1$ & $11 \pm 1$ & $48-72^{\mathrm{b}}$ \\
HNF & $37 \pm 5$ & $14 \pm 1$ & $0-48^{\mathrm{c}}$ \\
\hline
\end{tabular}
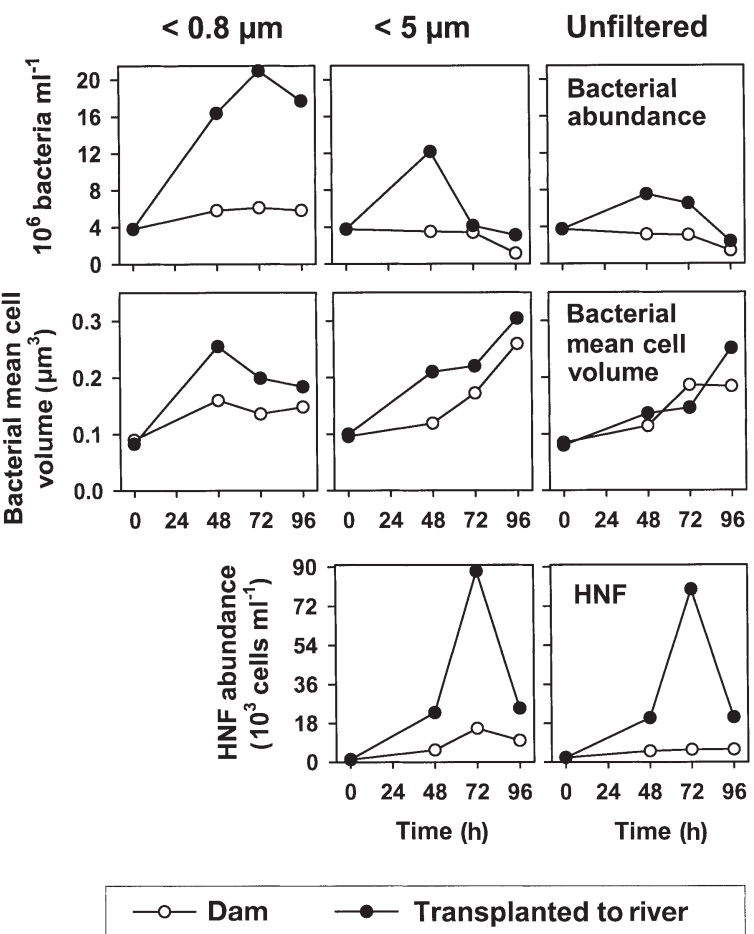

Fig. 1. Time-course changes in microbial parameters in different size fractionation treatments, $<0.8 \mu \mathrm{m},<5 \mu \mathrm{m}$ and unfiltered reservoir water, exposed in dialysis bags at the dam area of the reservoir compared to the changes in the same size fractions that were transplanted upstream to the river inflow of the reservoir. Upper panels, bacterial abundances; central panels, bacterial mean cell volumes; lower panels, abundances of heterotrophic nanoflagellates (HNF). Values are means for 2 replicate treatments

ples (Unf) showed largely similar trends in the dam and river incubations (Fig. 1). In the $<5 \mu \mathrm{m}$ dam sample, HNF grazing reduced bacterial numbers to only $1.2 \times 10^{6}$ cells $\mathrm{ml}^{-1}$ by the end of the incubation, accompanied by a decrease in bacterial production (Fig. 2). Moreover, a marked increase in MCV and overall structural and morphological shifts were observed: by the end of the incubation, 22 and $26 \%$ of total bacterial numbers were found as grazing-resistant flocs and filaments, respectively (Fig. 3). Trends in the $<5 \mu \mathrm{m}$ river treatment were similar (Figs. $1 \& 2$ ), although the magnitude of the shifts (except MCV) were much larger, by a factor of 4 to 5 . However, there were a few important differences between the $<5 \mu \mathrm{m}$ river and the $<5 \mu \mathrm{m}$ dam populations: (1) In the $<5 \mu \mathrm{m}$ river sample, there was an initial rise in bacterial abundance (from 3.8 to $12.1 \times 10^{6}$ cells ml$^{-1}$ ) between $t_{0}$ and $t_{48}$, despite a steep increase in the HNFpredator population. (2) The initial phase of the development of the grazing-resistant bacterial populations was much faster in the $<5 \mu \mathrm{m}$ river ( $>30 \%$ of total bacteria already at $t_{48 ;}$ Fig. 3) compared to the $<5 \mu \mathrm{m}$ dam 


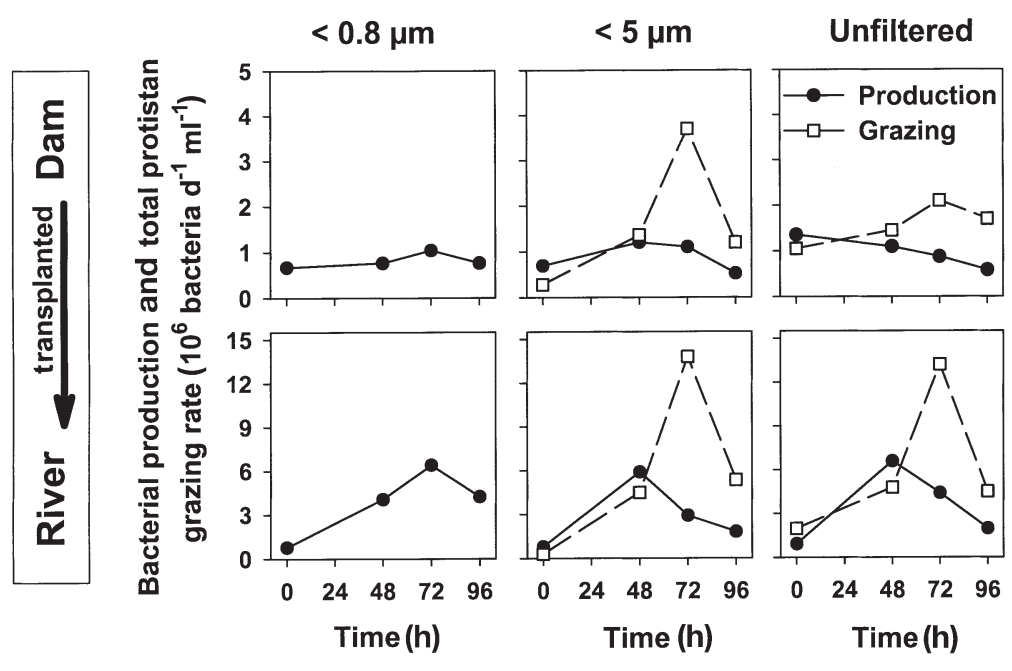

Fig. 2. Time-course changes in bacterial production and total protistan bacterivory in different size fractionation treatments, $<0.8 \mu \mathrm{m},<5 \mu \mathrm{m}$ and unfiltered reservoir water, exposed in dialysis bags at the dam area of the reservoir compared to the changes in the same size fractions that were transplanted upstream to the river inflow of the reservoir. Values are means for 2 replicate treatments. Note different scales for bacterial production and total protozoan grazing in the transplanted treatments

sample, but was composed almost entirely of small flocs of bacteria, followed by a shift toward the dominance of grazing-resistant filaments by the end of the incubation.

Among samples incubated at the same site, several site-specific phenomena were noted. For example, in the presumably more resource-limited dam incubations, bacterial abundance in unfiltered dam sample showed a trend almost indistinguishable from the one observed in $<5 \mu \mathrm{m}$ dam sample (Fig. 1). However, in the unfiltered dam sample, the bacterial population consisted of a smaller proportion of floc- and filament-forming bacteria (Fig. 3) corresponding with only a slight increase in HNF numbers. This suggests an important role of zooplankton in structuring HNF and thereby bacterial communities at the dam site.

Very different trends were noted among river-incubated samples. Data on bacterial abundance and MCV and HNF abundance were remarkably similar in the unfiltered river and $<5 \mu \mathrm{m}$ river populations (Fig. 1), indicating that the top-down control of HNF was considerably weaker. Although a comparable zooplankton community was present in the unfiltered river sample (Table 3), few effects were detected (Figs. 1 \& 2). For instance, shifts in bacterial production and loss rates as well as HNF growth in the unfiltered river sample were almost indistinguish- able from those observed in the $<5 \mu \mathrm{m}$ river sample. The net doubling time of grazed HNF in the unfiltered river sample was only slightly longer than that calculated for ungrazed HNF populations in the $<5 \mu \mathrm{m}$ river sample (Table 2). In addition, a large proportion of bacteria in the unfiltered river sample were 'grazing resistant' floc- and filament-forming (Fig. 3), suggesting that there was little top-down control of HNF by metazooplankton or ciliates. Perhaps the less pronounced peaks of bacteria at $t_{48}$ and of $\mathrm{HNF}$ at $t_{72}$ in the unfiltered river sample, as opposed to the $<5 \mu \mathrm{m}$ river treatment, could be attributed to the combined effect of zooplankton and ciliate grazing. Ciliate abundance (Table 3) slightly increased during the incubation in both unfiltered treatments, but had a significant impact on bacterial mortality only in the resource-limited unfiltered dam treatment (data not shown). There was no discernible treatment effect on the zooplankton. The original zooplankton composition remained unchanged throughout the experimental period in both dam and river unfiltered incubations (Table 3), except for an increase in rotifer abundance at the dam site.
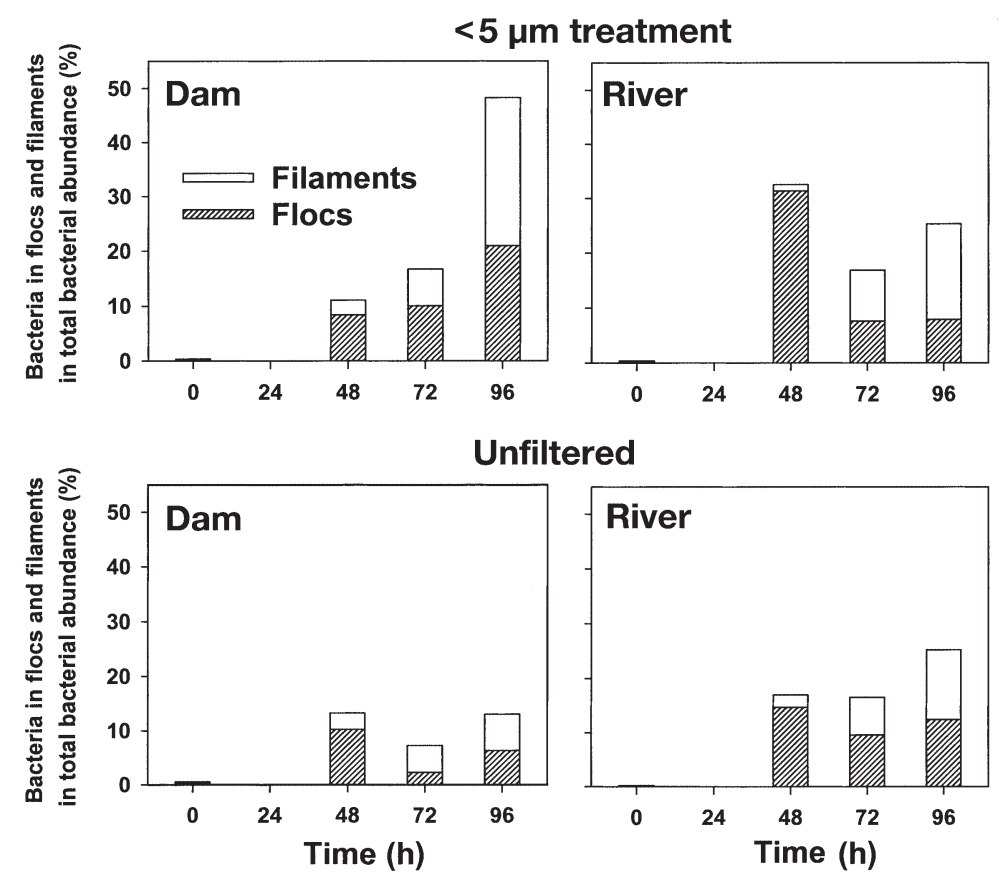

Fig. 3. Changes in the proportions of the abundance of floc- and filamentforming bacteria exposed to heavy grazing pressure under different resource availability at the dam and river sites for the $<5 \mu \mathrm{m}$ and unfiltered treatments exposed at the dam and transplanted to the river (for details see Table 1). Values are means for 2 replicate treatments 
Table 3. Comparison of zooplankton composition at the beginning of the experiments in the reservoir water and at the end of the experiment in the unfiltered treatments exposed at the dam area and transplanted to the river site. Only those species or groups of zooplankton whose abundance was $>1$ ind. $\mathrm{l}^{-1}$ are listed. The values are given as the range of the 2 duplicate treatments

\begin{tabular}{|c|c|c|c|}
\hline Zooplankton composition & $\begin{array}{c}\text { Reservoir water } \\
t_{0}\end{array}$ & $\begin{array}{l}\text { Unfiltered treatment exposed } \\
\text { at the dam site } t_{96} \\
\text { (ind. } \mathrm{l}^{-1} \text { ) }\end{array}$ & $\begin{array}{l}\text { Unfiltered treatment transplanted } \\
\text { to the river site } t_{96}\end{array}$ \\
\hline Daphnia galeata & $51-55$ & $48-61$ & $60-80$ \\
\hline Diaphanosoma brachyurum & $5-7$ & $13-15$ & $3-6$ \\
\hline Eudiaptomus gracilis & $10-14$ & $8-10$ & $16-26$ \\
\hline Adults of cyclops ${ }^{a}$ & $16-18$ & $15-21$ & $14-18$ \\
\hline Nauplii of all Copepoda & $25-31$ & $40-48$ & $37-43$ \\
\hline Filter feeding rotifers ${ }^{\mathrm{b}}$ & $7-9$ & $42-64$ & $4-6$ \\
\hline Polyarthra sp. & $2-2$ & $3-1$ & $1-3$ \\
\hline Asplanchna sp. & $4-2$ & $8-10$ & $2-2$ \\
\hline Total ciliates & $10900-14000$ & $43000-47500$ & $31200-35200$ \\
\hline
\end{tabular}

\section{Changes in bacterial community composition in different treatments}

With the exception of the ALF and R-FL groups of bacteria, which were always found at $<2 \%$ of the community, shifts in bacterial community composition (BCC; Fig. 4) were obvious. In the transplanted populations (river treatments), the increases in bacterial production were accompanied by increases in the proportions of cells detectable with the Eubacteria probe (EUB) at $t_{48}$ and $t_{72}$ (from $~ 50$ to $75-85 \%$ of total DAPIstained bacteria). A very similar, but much less pronounced, pattern of EUB-positive bacteria was also found in the dam incubations (Fig. 4).

Across all treatments, transplanting the samples to the river site resulted in significant increases (2-way ANOVA; Table 4$)$ in the proportions of EUB $(\mathrm{p}<0.001)$ at $t_{48}$ and $t_{72}$, as well as in the proportions of $\beta$ proteobacteria (BET, p < 0.001) and $\gamma$-protebacteria (GAM), differences which were significant throughout the whole incubation (Table 4). Changes in the proportions of the bacteria detected with the probe R-BT (a $\beta$ proteobacteria sub-cluster) were also significant for all the transplanted samples regardless of the incubation times (Table 4), however, with more pronounced treat-

Fig. 4. Time-course changes in the phylogenetic composition of the bacterioplankton community in size fractionation treatments, $<0.8 \mu \mathrm{m},<5 \mu \mathrm{m}$ and unfiltered reservoir water, exposed in dialysis bags at the dam area of the reservoir compared to the changes in the same size fractions that were transplanted upstream to the river inflow of the reservoir. Proportions of total fluorescence in situ hybridisation (FISH) detection rates by the general bacterial probe EUB and $\beta$-proteobacteria (BET), and the cells detected by probe R-BT, $\gamma$ proteobacteria (GAM) and Cytophaga/Flavobacterium group (CF). Values are means for 2 replicate treatments ment-specific features (see below). Overall, transplanting the populations to the river site clearly resulted in strong and significant impacts on BCC in all treatments (see Table 4), while relatively few size-fractionation (top-down) effects could be detected.

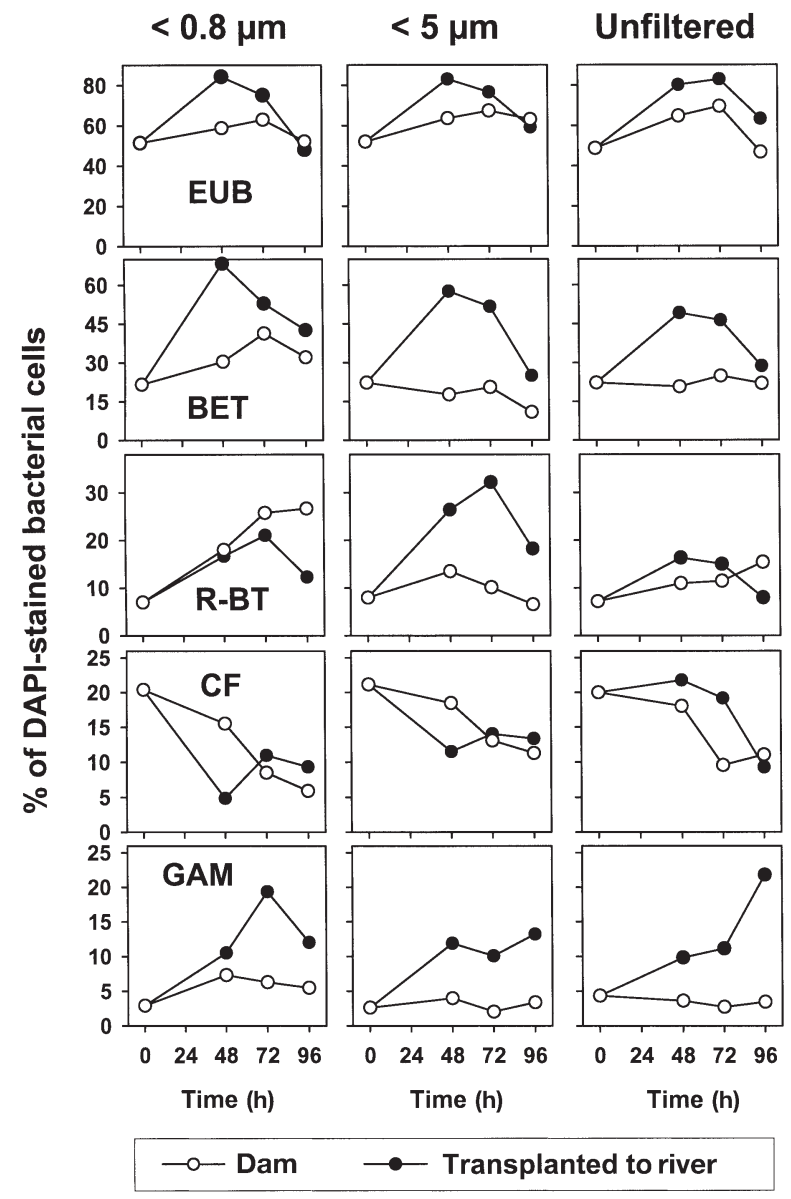


Table 4. Results of 2-way ANOVA ( $F$-values) used to test for differences in bacterial community composition (BCC) between the dam and river incubations across all experimental variants at $t_{48}, t_{72}$ and $t_{96}$. Tested were differences in the relative contributions (as \% of total DAPI-stained bacteria) of 5 different phylogenetic groups of bacteria targeted by the probes EUB, BET, R-BT, CF and GAM (for details see Fig. 4) induced by filtration of water samples (not shown, but see Table 5), and by transplanting the samples from the dam area to the river site. ${ }^{*} p<0.05,{ }^{* *} p<0.01,{ }^{* * *} p<0.001$

\begin{tabular}{|lccc|}
\hline Probe & \multicolumn{3}{c|}{ Dam sample transplanted to the river } \\
& \multicolumn{3}{c|}{$(F$-value $)$} \\
& $t_{48}$ & $t_{72}$ & $t_{96}$ \\
\hline EUB & $211^{* * *}$ & $31.4^{* *}$ & 3.96 \\
BET & $232^{* * *}$ & $95.5^{* * *}$ & 2.38 \\
R-BT & $10.6^{*}$ & $52.3^{* * *}$ & $8.87^{*}$ \\
CF & $16.8^{* *}$ & 5.93 & 1.80 \\
GAM & $137^{* * *}$ & $117^{* * *}$ & $18.3^{* *}$ \\
& & & \\
\hline
\end{tabular}

Table 5 shows results of a 1-way ANOVA followed by pair-wise comparisons (Tukey's HSD test) between individual treatments incubated at the dam and river, respectively. Significant differences were associated with the top-down manipulations in dam-incubated samples, while at the river site, transplanting the samples (bottom-up-induced changes; Table 4) overwhelmed or obscured the impacts of size fractionation. For example, with regard to the cells targeted by the probe R-BT, the top-down manipulation induced significant shifts mainly among dam incubations (Table 5). Thus, in the $<0.8 \mu \mathrm{m}$ dam samples, the ungrazed R-BT populations of bacteria showed the most marked increase, as they did also in the unfiltered dam sample, but much less evidently. In contrast, a decreasing trend for this phylogenetic group was observed in the heavily grazed $<5 \mu \mathrm{m}$ dam treatment between $t_{48}$ and $t_{96}$ (Fig. 4). Changes in the R-BT as well as in BET proportions in the $<0.8 \mu \mathrm{m}$ dam treatment were significantly different from those observed in the other 2 dam treatments at $t_{96}$ (Table 5; Tukey's HSD test), yielding the most significant differences between $<0.8$ and $<5 \mu \mathrm{m}$ dam treatments $(p<0.01)$. In contrast, in the riverincubated populations, few significant differences between treatments were found with regard to R-BT bacteria. A single large change occurred among R-BTpositive bacteria in $<5 \mu \mathrm{m}$ river samples, where they increased from 7 to $\sim 33 \%$ of total bacteria (Fig. 4) during the first $72 \mathrm{~h}$ of the incubation, resulting in significant differences compared to the other 2 river treatments (Table 5).

The proportion of bacteria found to belong to the Cytophaga/Flavobacterium cluster (CF) showed a decreasing trend in all treatments incubated at the dam (Fig. 4), while at $t_{96}$ the $<0.8 \mu \mathrm{m}$ dam treatment was significantly different from both $<5 \mu \mathrm{m}$ and unfiltered dam treatments $(\mathrm{p}<0.05)$. Overall, transplanting dam samples to the river site induced significant changes in the proportions of CF-positive cells only at $t_{48}(\mathrm{p}<0.01$; Table 4$)$. Moreover, within all of the treatments incubated at the river, significant differences in the CF proportions were found at $t_{48}$ (Table 5). The transplanted CF populations, after an initial drop in the $<0.8$ and $<5 \mu \mathrm{m}$ river treatments, increased again between $t_{48}$ and $t_{72}$ (Fig. 4). Only in the unfiltered river

Table 5. Results of 1-way ANOVA followed by pair-wise comparisons of significant differences (Tukey's HSD test) between individual treatments at $t_{48}, t_{72}$ and $t_{96}$ incubated at the dam and river sites. Tested were treatment-specific differences in the relative contributions (as \% of total DAPI-stained bacteria) of 5 different phylogenetic groups of bacteria targeted by the probes EUB, BET, R-BT, CF and GAM (see Fig. 4 for details). The significant differences are shown in bold. $(\mathrm{p}<0.05, \mathrm{p}<0.01$ ). ns: not significant, Unf: unfiltered treatment

\begin{tabular}{|c|c|c|c|c|c|c|c|}
\hline \multirow[t]{2}{*}{ Probe } & \multirow[t]{2}{*}{ Treatments tested } & \multicolumn{3}{|c|}{ Dam incubations } & \multicolumn{3}{|c|}{ River incubations } \\
\hline & & $t_{48}$ & $t_{72}$ & $t_{96}$ & $t_{48}$ & $T_{72}$ & $t_{96}$ \\
\hline \multirow[t]{3}{*}{ EUB } & $<0.8 \mu \mathrm{m}$ vs $<5 \mu \mathrm{m}$ & ns & ns & $<0.05$ & ns & ns & ns \\
\hline & $<0.8 \mu \mathrm{m}$ vs Unf & ns & $\mathrm{ns}$ & ns & ns & ns & ns \\
\hline & $<5 \mu \mathrm{m}$ vs Unf & ns & ns & $<0.01$ & ns & ns & ns \\
\hline \multirow[t]{3}{*}{ BET } & $<0.8 \mu \mathrm{m}$ vs $<5 \mu \mathrm{m}$ & $<0.05$ & $<0.05$ & $<0.01$ & ns & ns & ns \\
\hline & $<0.8 \mu \mathrm{m}$ vs Unf & ns & ns & $<0.05$ & ns & ns & ns \\
\hline & $<5 \mu \mathrm{m}$ vs Unf & ns & $\mathrm{ns}$ & $<0.05$ & ns & ns & ns \\
\hline \multirow[t]{3}{*}{ R-BT } & $<0.8 \mu \mathrm{m}$ vs $<5 \mu \mathrm{m}$ & ns & $<0.01$ & $<0.01$ & ns & $<0.05$ & ns \\
\hline & $<0.8 \mu \mathrm{m}$ vs Unf & ns & $<0.01$ & $<0.05$ & ns & ns & ns \\
\hline & $<5 \mu \mathrm{m}$ vs Unf & ns & ns & $<0.05$ & ns & $<0.01$ & ns \\
\hline \multirow[t]{3}{*}{$\mathrm{CF}$} & $<0.8 \mu \mathrm{m}$ vs $<5 \mu \mathrm{m}$ & ns & ns & $<0.05$ & $<0.05$ & ns & ns \\
\hline & $<0.8 \mu \mathrm{m}$ vs Unf & ns & ns & $<0.05$ & $<0.01$ & ns & ns \\
\hline & $<5 \mu \mathrm{m}$ vs Unf & $\mathrm{ns}$ & $\mathrm{ns}$ & ns & $<0.05$ & ns & ns \\
\hline \multirow[t]{3}{*}{ GAM } & $<0.8 \mu \mathrm{m}$ vs $<5 \mu \mathrm{m}$ & $<0.05$ & $<0.05$ & $<0.05$ & ns & $<0.01$ & ns \\
\hline & $<0.8 \mu \mathrm{m}$ vs Unf & $<0.05$ & ns & $<0.05$ & ns & $<0.05$ & ns \\
\hline & $<5 \mu \mathrm{m}$ vs Unf & ns & ns & ns & ns & ns & ns \\
\hline
\end{tabular}


treatment did the CF populations respond differently: during the first half of the experiment the proportion increased, while towards the end of the incubation they dropped dramatically (Fig. 4). With regard to the proportions of bacteria targeted by the probe GAM, they consistently showed increases only in the samples transplanted to the river site (Fig. 4). Significant differences between $<0.8$ and $<5 \mu \mathrm{m}$ or Unf treatments were found more frequently among the dam treatments (Table 5), while significant only at $t_{72}$ for the river treatments. In contrast, throughout the whole incubation, neither at the dam nor at river sites were the differences in the GAM proportions between $<5 \mu \mathrm{m}$ and Unf treatments significant (Table 5).

Overall, a relaxation of resource limitation in river treatments was shown by the much shorter doubling times for all groups of river-compared to damincubated bacteria (especially for the BET and GAM groups) and total HNF (doubling times between 11 to $14 \mathrm{~h})$; this was despite the lower water temperature in the river incubations (by between 5 and $6^{\circ} \mathrm{C}$ ). The only exception was $\mathrm{CF}$ bacteria, which appeared to grow slower in river-relative to dam-incubated samples (Table 3).

\section{DISCUSSION}

Our previous experiments conducted at the resource-limited dam area of the reservoir, when only the top-down manipulation approach was used (size fractionation of samples), documented strong impacts of grazing on bacterial dynamics and BCC (Šimek et al. 1999, 2001b) with shifts in bacterial communities easily relatable to changes in the balance between bacterial population-specific growth and removal rates (Šimek et al. 2002).

In this study, we performed a transplant experiment designed to test the hypothesis that the impact of topdown manipulation (i.e. exposing bacteria to different size fractions of predators) could be altered by a bottom-up response in growth and physiology of bacteria, induced when transplanted to a nutrient-rich environment. The transplanted microorganisms grew in an environment different from the one in which they were originally growing, with dialysis bags acting as a sort of a 'cage' permitting exposure of differently topmanipulated communities to an enhanced resource availability (Table 1). We found that changes in the bacterioplankton, resulting from a shift in resource availability, could dominate those resulting from changes in grazing pressure (Figs. 1, 2\& 4). Thus, we considerably extended the conclusions of previous field studies which focused largely on the effects of grazers of bacteria (e.g. Jürgens et al. 1999, Šimek et al. 1999, 2001b).

\section{Resource-induced physiological and growth responses of microbial communities}

Consistent patterns were apparent in our data: in the resource-limited dam area, the amplitude of the growth response of the non-grazed bacterial and HNF populations (the $<0.8$ and $<5 \mu \mathrm{m}$ treatments) was far less pronounced than those observed in the corresponding transplanted treatments, and the zooplankton present in the unfiltered dam treatment (Table 3) efficiently controlled HNF dynamics (Fig. 1). Thus, these data were in accordance with studies of different systems, documenting a strong structuring effect of zooplankton grazing that cascades down to the level of bacteria (Christoffersen et al. 1990, Pace et al. 1990), previously described for the Rímov reservoir during the clear-water phase (Šimek et al. 1990). The very limited growth of bacteria (Fig. 1) in the predator-free $(<0.8 \mu \mathrm{m})$ dam treatment is likely due to a lack of $\mathrm{P}$ at the dam area (cf. also Nedoma et al. 1993) since no marked differences in DOC were found between the sites.

In contrast, in all the transplanted treatments, we observed marked, 3- to 6-fold, increases in bacterial and HNF growth rates and concentrations. Another commonality among transplanted communities was an increase in numbers of viruses and viral-induced bacterial mortality (Weinbauer et al. 2003, this issue). The increases in bacterial abundance and production in our transplanted samples (Figs. 1 \& 2) were accompanied by 2 sources of bacterial mortality: (1) an increase in viral abundance and virus-induced mortality of bacteria (for details see Weinbauer et al. 2003); and (2) an increase in HNF abundance and total protistan bacterivory (Figs. 1 \& 2). Thus, trophic levels directly dependent on bacterial dynamics and production followed bacterioplankton dynamics. In contrast, the zooplankton present in the unfiltered river samples (Table 3) did not efficiently control the bottom-up induced development of total, filament- and floc-forming bacteria and HNF in this treatment (Figs. 1, 2 \& 3).

Another consistent trend, valid for both dam and river $<5 \mu \mathrm{m}$ treatments and found also in the previous studies (cf. Šimek et al. 1999, 2001b), was a pattern of HNF numbers and bacterivory exceeding bacterial production, coupled with an increase in average bacterial cell size, in the second half of the experiment (Figs. 1 \& 2). Our estimates of bacterivory exceeding production are due in part to the use of FLB uptake, which basically measures only the ingestion of relatively small, non-filamentous or floc-associated cells. However, grazing-resistant flocs were generally considered only those $>3$ to $4 \mu \mathrm{m}$ (cf. Hahn \& Höfle 2001). Correspondingly, Fig. 3 presents only the grazingresistant bacteria in the larger flocs, while significant 
proportions of very small flocs, composed of only 2 to 6 cells, were also observed in $<5 \mu \mathrm{m}$ and Unf treatments, and they were included in the total number of edible bacterial prey used for calculation of the tracer FLB added. Since those small bacterial flocs were perhaps not ingested by small HNF, estimates of HNF grazing rate, calculated for the whole bacterial community, are probably overestimates.

The period of intense bacterivory was paralleled by a marked increase in viral numbers and virus-induced bacterial mortality accounting for 39 and $66 \%$ of daily bacterial production in the $<5 \mu \mathrm{m}$ dam and river treatments, respectively (for details see Weinbauer et al. 2003). Thus, the treatments with highest protistan predation pressure (Fig. 2) also consistently had the highest virus:bacterium ratio and highest viral infection rates. A combination of 2 factors, i.e. prey-selective protistan bacterivory and host-specific viral infection, yielded likely a synergistic effect (cf. also Šimek et al. $2001 b)$, accelerating the observed changes in BCC, apparent at the river site (Fig. 4, Table 5). Since nutrient limitation can significantly reduce host availability and in turn also virus production (Tuomi et al. 1995), not surprisingly, the contribution of virus-induced mortality to the total bacterial loss rate was greater in the resource-rich river site (Weinbauer et al. 2003). Thus, our data indicate that viruses might have stronger impacts on shaping BCC in a resource-rich environment, while grazing-induced impacts on BCC seem to be more important in a resource-limited environment (Fig. 4).

\section{Top-down and bottom-up induced changes in bacterioplankton community composition}

Transplanting the samples yielded large shifts in $\mathrm{BCC}$, larger than those associated with changes in grazing pressure (cf. Tables 4 \& 5), resembling partly the conclusions drawn from a similar 'transplant' study conducted in a highly eutrophic, canyon-shaped reservoir in Spain (for details see Gasol et al. 2002). In all the communities transplanted to the river site, significant changes occurred in the proportions of all probedetected groups of bacterial phylotypes (Table 4); this was most evident for BET, R-BT and GAM (Fig. 4). The increases in proportions of the cells targeted by the universal probe EUB, at $t_{48}$ and $t_{72}$, from $\sim 57$ to $85 \%$ of total DAPI-stained bacteria in the transplanted samples, indicated increases in proportions of bacteria with the enhanced number of ribosomes per cell (Poulsen et al. 1993).

The BCC shifts in the river-incubated communities consisted of significant changes within all targeted groups, generally as increases in growth rate and relative importance (Fig. 4, Tables 2, 4 \& 5). However, the group-specific probes we used only permitted division of the community into a few groups, each of which consists of an unknown number of bacterial strains. The probes ALF and the highly specific R-FL, used to identify a large number of filamentous bacteria at the dam area in the previous studies (Šimek et al. 1999, 2001b), consistently detected less than 1 to $2 \%$ of total bacteria regardless of treatment or incubation site (data not shown). Thus, lacking more specific information on $\mathrm{BCC}$, we can only speculate about the precise nature of changes among various bacterial phylotypes in the transplanted samples. Our data could partly reflect a generally enhanced detection limit of the FISH approach for the same groups of phylotypes transplanted to the river or, more specifically, it could indicate a marked stimulation of the growth of certain groups of bacteria that were perhaps formerly resource-deficient, thus less active and growing slowly at the dam area.

The most dramatic increases were found for the clusters typically dominant in freshwater that were targeted by the BET probe and tripled their proportions within $48 \mathrm{~h}$ (up to $68 \%$ in the $<0.8 \mu \mathrm{m}$ dam sample) and for GAM that showed a 5-fold increase at $t_{96}$ (see Unf-river, Fig. 4). Both these groups have been considered as indicators of allochthonous organic pollution (Manz et al. 1994), with the GAM phylotypes usually dominating the culturable part of a community (Glöckner et al. 1999). Unfortunately, we have very limited knowledge about the composition of DOC in the river site, except for relative increases in the proportion of humic substances and decrease of algal biomass and exudates (J. N. unpubl. data), compared to the dam area. However, it is very likely that easily degradable DOC of anthropogenic origin accounted for part of DOC in the river site, contributing, together with the enhanced P-availability, to the conspicuous growth response of microbial communities (Fig. 1).

The members of the CF lineage, reported as numerically dominating members of the domain bacteria on limnetic aggregates (Weiss et al. 1996, Kirchman 2002), were the only group whose growth rate and relative importance decreased as a response to transplanting. This could indicate that among them, there are typical pelagic bacterial groups unrelated to allochthonous pollution (e.g. Weiss et al. 1996, Šimek et al. 1999, 2001a) that were more competitive under resource-limited conditions including enhanced proportion of algal exudates in DOC (J. N. unpubl. data) in the lacustrine part of the reservoir.

A specifically designed probe for the reservoir bacterioplankton (R-BT, for details see Šimek et al. 2001b) targets a numerically important freshwater cluster of $\beta$-proteobacteria (accounting for $~ 10$ to $35 \%$ of total bacteria) with an apparently cosmopolitan 
distribution (Glöckner et al. 2000). This bacterial lineage enabled us to get the finest resolution in terms of the discrimination between treatment-specific bottom-up and top-down effects (Table 5). Moreover, it yielded very consistent patterns with the outcome of the previous study (see Šimek et al. 2001b, cf. Fig. 4 in this study). For instance, the R-BT lineage showed similar increases in both dam and river bacterivore-free treatments, while a different trend in the HNFenhanced $(<5 \mu \mathrm{m})$ treatments was observed with a treatment-specific dramatic rise at the river site (Fig. 3). In contrast, the smallest changes, and no clear trend in the proportions of the R-BT lineage, was found in unfiltered treatments, where prey-selective protistan bacterivory and filtering pressure of metazooplankton acted in parallel.

Comparisons of significant differences (Table 5) between individual treatments showed much more pronounced differences between the treatments incubated at the dam site compared to those in the resource-rich river. Moreover, the pair-wise comparison for dam data only (Table 5), showed more significant differences, in terms of proportions of different bacterial groups, between the bacterivore-free $<0.8 \mu \mathrm{m}$ dam sample on the one hand, and $<5 \mu \mathrm{m}$ or unfiltered dam sample on the other. In contrast, between the 2 latter treatments, with the presence of grazing pressure (either of HNF only or of HNF and zooplankton), the significant differences (Table 5) were detected only rarely (EUB, BET and R-BT) and exclusively at the very end of the incubation. Overall, we found a strong effect of grazing on $\mathrm{BCC}$ at the dam site that was overwhelmed by the bottom-up-induced changes in the river treatments.

Protistan grazing also induced distinct changes in bacterial size structure (Fig. 3) as it was associated with increases in proportions of floc- and filament-forming bacteria. Although these 2 grazing-resistant morphotypes (for recent review see Hahn \& Höfle 2001) were attributable to BET and CF lineages in more than $95 \%$ of the cases, we did not specifically analyse the structure of the flocs as we had done in a previous study (Šimek et al. 2001b). In addition, we found that $\sim 4$ to $15 \mu \mathrm{m}$ long filaments of various taxonomic affiliation accounted for 17 to $26 \%$ of total bacteria in the $<5 \mu \mathrm{m}$ treatments (Fig. 3) compared to a previous study in which filaments represented 1 to $7 \%$ and most of them were members of the Flectobacillus lineage (see Fig. 3 in Šimek et al. 2001b). Thus, the capability of bacteria to form filaments as a response to grazing pressure appears widespread among different phylogenetic groups (cf. Hahn et al. 1999, Šimek et al. 1999, 2001b, Langenheder \& Jürgens 2001).

To sum up, we observed large changes in bacterioplankton community composition, size structure and dynamics, and HNF growth rate and community bacterivory induced by manipulating both top-down (grazing pressure) and bottom-up (resource availability) factors. Obviously, an interplay of the factors regulating bacterioplankton dynamics and BCC operate differently in spatially heterogeneous systems (cf. Gasol et al. 2002), with more pronounced impacts of top-down control in the resource-limited dam area, while impacts of bottom-up factors clearly dominated in the resource-rich river inflow to the reservoir. This study also documented marked increases in physiological rates of bacteria transplanted from a resourcelimited regime to the resource-rich one, under which, on a short time-scale (days), the bacterial community escaped control by predation. The period of imbalance between bacterial production and mortality corresponded to period of change in BCC. Thus, we found evidence using natural populations incubated in situ to support the intuitively obvious idea that shifts in either resources or grazing causes changes in BCC (Šimek et al. 2002).

Acknowledgements. This study was supported by the Grant Agency of the Czech Republic by the research grants awarded to K.Š. (206/99/0028, 206/02/0003), by a CzechGreek joint project KONTAKT $(22-2000 / 9513514$ given to K.Š.), by the CNRS through the PICS 1111 project (Regulation of Heterotrophic Planktonic Prokaryotes given to J.R.D.) and by the project MSM (Structure and functioning of the system water-soil-plant; 123100004). We wish to thank Josep Gasol for the valuable comments on the earlier versions of the paper, Josef Hejzlar for supplying chemical data and Zdeněk Prachař for counting zooplankton samples.

\section{LITERATURE CITED}

Alfreider A, Pernthaler J, Amann R, Sattler B, Glöckner FO, Ville A, Psenner R (1996) Community analysis of the bacterial assemblages in the winter cover and pelagic layers of a high mountain lake using in situ hybridization. Appl Environ Microbiol 62:2138-2144

Amann RI, Ludwig W, Schleifer KH (1995) Phylogenetic identification and in situ detection of individual microbial cells without cultivation. Microbiol Rev 59:143-169

Berninger UG, Finlay BJ, Kuuppo-Leinikki P (1991) Protozoan control of bacterial abundances in freshwaters. Limnol Oceanogr 36:139-147

Christoffersen K, Riemann B, Hansen LR, Klysner A, Sørensen HB (1990) Quantitative importance of the microbial loop and plankton community structure in a eutrophic lake during a bloom of cyanobacteria. Microb Ecol 20: $253-272$

Chrzanowski TH, Šimek K (1990) Prey-size selection by freshwater flagellated protozoa. Limnol Oceanogr 35: 1429-1436

Chrzanowski TH, Sterner RW, Elser JJ (1995) Nutrient enrichement and nutrient regeneration stimulate bacterioplankton growth. FEMS Microb Ecol 29:221-230

Comerma M, Garcia JC, Armengol J, Romero M, Šimek K (2001) Planktonic food web structure along the Sau 
Reservoir (Spain) in summer 1997. Int Rev Hydrobiol 86: 193-207

Eilers H, Pernthaler J, Amann R (2000) Succession of pelagic marine bacteria during enrichment: a close look on cultivation-induced shifts. Appl Environ Microbiol 66:4634-4640

Fuhrman JA (1999) Marine viruses and their biogeochemical and ecological effects. Nature 399:541-548

Gasol JM, Duarte CM (2000) Comparative analyses in aquatic microbial ecology: how far do they go? FEMS Microbiol Ecol 31:99-106

Gasol JM, Comerma M, Garcia JC, Casamayor EO, Armengol J, Kojecká P, Šimek K (2002) A transplant experiment to identify the factors controlling bacterial abundance, activity, production and community composition in a eutrophic canyon-shaped reservoir. Limnol Oceanogr 47:62-77

Glöckner FO, Fuchs BM, Amann R (1999) Bacterioplankton compositions of lakes and oceans: a first comparison based on fluorescence in situ hybridization. Appl Environ Microbiol 65:3721-3726

Glöckner FO, Zaichikov E, Belkova N, Denissova L, Pernthaler J, Pernthaler A, Amann R (2000) Comparative 16S rRNA analysis of lake bacterioplankton reveals globally distributed phyogenetic clusters including an abundant group of Actinobacteria. Appl Environ Microbiol 66: 5053-5065

Hahn MW, Höfle MG (2001) Grazing of protozoa and its effect on populations of aquatic bacteria. FEMS Microb Ecol 35: 113-121

Hahn MW, Moore ERB, Höfle MG (1999) Bacterial filament formation, a defense mechanism against flagellate grazing, is growth rate controlled in bacteria of different phyla. Appl Environ Microbiol 65:25-35

Jürgens K (1994) Impact of Daphnia on planktonic microbial food webs: a review. Mar Microb Food Webs 8:295-324

Jürgens K, Pernthaler J, Schalla S, Amann R (1999) Morphological and compositional changes in a planktonic bacterial community in response to enhanced protozoan grazing. Appl Environ Microbiol 65:1241-1250

Kirchman DL (2002) The ecology of Cytophaga-Flavobacteria in aquatic environments. FEMS Microb Ecol 39:91-100

Kopáček J, Hejzlar J (1993) Semi-micro determination of total phosphorus in fresh waters with perchloric acid digestion. Int J Environ Anal Chem 53:173-183

Langenheder S, Jürgens K (2001) Regulation of bacterial biomass and community structure by metazoan and protozoan predation. Limnol Oceanogr 46:121-134

Lorensen CJ (1967) Determination of chlorophyll and phaeopigments: spectrophotometric equations. Limnol Oceanogr 12:343-346

Manz W, Wagner M, Amann R, Schleifer KH (1994) In situ characterization of the microbial consortia active in two wastewater treatment plants. Water Res 28:1715-1723

McCauley E (1984) The estimation of the abundance and biomass of zooplankton in samples. In: Downing JA, Rigler FH (eds) A manual on methods for the assessment of secondary productivity in fresh waters. Blackwell Scientific Publications, Oxford, p 228-266

Nedoma J, Porcalová P, Komárková J, Vyhnálek V (1993) A seasonal study of phosphorus deficiency in a eutrophic reservoir. Freshw Biol 30:369-376

Norland S (1993) The relationship between biomass and volume of bacteria. In: Kemp PF, Sherr BF, Sherr EB, Cole JJ (eds) Handbook of methods in aquatic microbial ecology. Lewis Publishers, Boca Raton, FL, p 303-308

Pace ML, Cole JJ (1996) Regulation of bacteria by resources and predation tested in whole-lake experiments. Limnol Oceanogr 41:1448-1460
Pace ML, McManus GB, Findlay SEG (1990) Planktonic community structure determines the fate of bacterial production in a temperate lake. Limnol Oceanogr 35:795-808

Pernthaler J, Glöckner FO, Unterholzner S, Alfreider A, Psenner R, Amann R (1998) Seasonal community and population dynamics of pelagic Bacteria and Archaea in a high mountain lake. Appl Environ Microbiol 64:4299-4306

Pernthaler A, Pernthaler J, Eilers H, Amann R (2001a) Growth pattern of 2 marine isolates: adaptations to substrate patchiness? Appl Environ Microbiol 67:4077-4083

Pernthaler J, Posch T, Šimek K, Vrba J, Nübel U, Glöckner FO, Psenner R, Amann R (2001b) Predator-specific enrichment of Actinobacteria from a cosmopolitan freshwater clade in a mixed continuous culture. Appl Environ Microbiol 67:2145-2155

Posch T, Pernthaler J, Alfreider A, Psenner R (1997) Cellspecific respiratory activity of aquatic bacteria studied with the tetrazolium reduction method, cyto-clear slides and image analysis. Appl Environ Microbiol 63:867-873

Poulsen LK, Ballard G, Stahl DA (1993) Use of rRNA fluorescence in situ hybridization for measuring the activity of single cells in young and established biofilms. Appl Environ Microbiol 59:1354-1360

Riemann B, Søndergaard M (1986a): Regulation of bacterial secondary production in 2 eutrophic lakes and in experimental enclosures. J Plankton Res 8:519-536

Riemann B, Søndergaard M (1986b) Carbon dynamics in eutrophic, temperate lakes. Elsevier Science Publishers, Amsterdam

Riemann L, Steward GF, Azam F (2000) Dynamics of bacterial community composition and activity during a mesocosm diatom bloom. Appl Environ Microbiol 66:578-587

Sanders RW, Porter KG, Bennet SJ, DeBiase AE (1989) Seasonal patterns of bacterivory by flagellates, ciliates, rotifers, and cladocerans in a freshwater planktonic community. Limnol Oceanogr 34:673-687

Sanders RW, Caron DA, Berninger UG (1992) Relationship between bacteria and heterotrophic nanoplankton in marine and freshwaters: an inter-ecosystem comparison. Mar Ecol Prog Ser 86:1-14

Schäfer $\mathrm{H}$, Bernard L, Courties C, Lebaron P and 7 others (2001) Microbial community dynamics in Mediterranean nutrient-enriched seawater mesocosms: changes in the genetic diversity of bacterial populations. FEMS Microb Ecol 34:243-253

Schweitzer B, Simon M (1995) Growth limitation of planktonic bacteria in a large mesotrophic lake. Microb Ecol 30: 89-104

Sherr EB, Sherr BF (1993) Protistan grazing rates via uptake of fluorescently labelled prey. In: Kemp P, Sherr BF, Sherr EB, Cole J (eds) Handbook of methods in aquatic microbial ecology. Lewis Publishers, Boca Raton, FL, p 695-701

Šimek K, Macek M, Sed'a J, Vyhnálek V (1990) Possible food chain relationships between bacterioplankton, protozoans, and cladocerans in a reservoir. Int Rev Gesamten Hydrobiol 75:583-596

Šimek K, Vrba J, Pernthaler J, Posch T, Hartman P, Nedoma J, Psenner R (1997) Morphological and compositional shifts in an experimental bacterial community influenced by protists with contrasting feeding modes. Appl Environ Microbiol 63:587-595

Šimek K, Kojecká P, Nedoma J, Hartman P, Vrba J, Dolan DR (1999) Shifts in bacterial community composition associated with different microzooplankton size fractions in a eutrophic reservoir. Limnol Oceanogr 44:1634-1644

Šimek K, Armengol J, Comerma M, Garcia JC, Kojecká P, Nedoma J, Hejzlar J (2001a) Changes in the epilimnetic 
bacterial community composition, production, and protistinduced mortality along the longitudinal axis of a highly eutrophic reservoir. Microb Ecol 42:359-371

Šimek K, Pernthaler J, Weinbauer MG, Horňák K, Dolan JR, Nedoma J, Mašín M, Amann R (2001b) Changes in bacterial community composition, dynamics and viral mortality rates associated with enhanced flagellate grazing in a meso-eutrophic reservoir. Appl Environ Microbiol 67: $2723-2733$

Šimek K, Nedoma J, Pernthaler J, Posch T, Dolan JR (2002) Altering the balance between bacterial production and protistan bacterivory triggers shifts in freshwater bacterial community composition. Antonie Leeuwenhoek 81: $453-463$

Simon M, Azam F (1989) Protein content and protein synthesis rates of planktonic marine bacteria. Mar Ecol Prog Ser 51:201-213

Stell RGD, Torrie JH (1980) Principles and procedures of statistics, 2nd edn. McGraw-Hill, New York

Toolan T, Wehr JD, Findlay S (1990) Inorganic phosphorus stimulation of bacterioplankton production in a meso-

Editorial responsibility: Gunnar Bratbak, Bergen, Norway eutrophic lake. Appl Environ Microbiol 57:2074-2078

Tuomi P, Fagerbakke KM, Bratbak G, Heldal M (1995) Nutritional enrichment of a microbial community: the effects on activity, elemental composition, community structure and virus production. FEMS Microb Ecol 16:123-134

Van Hannen EJ, Zwart G, Van Agterveld MP, Gons HJ, Ebert J, Lannbroek HJ (1999) Changes in bactrerial and eukaryotic community structure after mass lysis of filamentous cyanobacteria with viruses. Appl Environ Microbiol 65: 795-801

Weinbauer MG, Šimek K, Christaki U, Nedoma J (2003) Comparing the effects of resource enrichment and grazing on viral production in a meso-eutrophic reservoir. Aquatic Microb Ecol 31:137-144

Weiss P, Schweitzer B, Amann R, Simon M (1996) Identification in situ and dynamics of bacteria on limnetic organic aggregates (lake snow). Appl Environ Microbiol 62: 1998-2005

Wright RT (1988) A model for short-term control of the bacterioplankton by substrate and grazing. Hydrobiologia 159: 111-117

Submitted: April 30, 2002; Accepted: October 31, 2002

Proofs received from author(s): February 4, 2003 